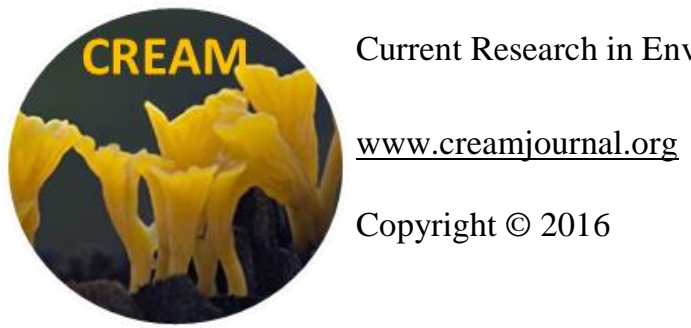

ISSN 2229-2225

Article

CREAM

Online Edition

Doi 10.5943/cream/6/1/1

\title{
Assessment of antioxidant potentials of the wild and domesticated saprophytic edible mushrooms from Tanzania
}

\author{
Juma $\mathrm{I}^{1}$, Mshandete $\mathrm{AM}^{2} *$, Tibuhwa $\mathrm{DD}^{3}$ and Kivaisi $\mathrm{AK}^{4}$ \\ Department of Molecular Biology \& Biotechnology, College of Natural \& Applied Sciences, Uvumbuzi Road, University of \\ Dar es Salaam, P.O. Box 35179, Dar es Salaam, Tanzania. \\ ${ }^{1}$ ibrahim.vuga@gmail.com \\ $2^{*}$ anthony.mshandete@yahoo.com \\ 3 dtibuhwa@yahoo.co.uk \\ ${ }^{4}$ amelia.kivaisi@gmail.com
}

Juma I, Mshandete AM, Tibuhwa DD, Kivaisi AK 2016 - Assessment of antioxidant potentials of the wild and domesticated saprophytic edible mushrooms from Tanzania. Current Research in Environmental \& Applied Mycology 6(1), 1-10, Doi 10.5943/cream/6/1/1

\begin{abstract}
Tanzania natural forests harbor several indigenous edible mushrooms that are meagerly exploited due to various reasons including unawareness on their potential values. This study establishes antioxidant potentials of seven wild edible mushroom species, and their two domesticated forms. The investigation used mushroom methanolic extract for antioxidant activities' determination. A DPPH (1, 1-diphenyl-2-picrylhydrazyl) radical was used as a substrate to determine radical scavenging abilities whereas ferrozine was employed to determine ferrous ion chelating abilities. Additionally, quantitative analyses for $\beta$-carotene, lycopene, flavonoids, and total phenolic compounds were done using spectrophotometric assay. Mushrooms analysed displayed amazing antioxidant potentials which varied between different species and between the wild and domesticated forms of the same species. The range of $\mathrm{EC}_{50}$ values for DPPH free radical scavenging activity (DRSA) was $0.075->0.3 \mathrm{mg} / \mathrm{mL}$, with the strongest and weakest $\mathrm{EC}_{50}$ recorded from P. tenuiculus and the wild Amylosporus sp. IJ-2014, respectively. The range of $\mathrm{EC}_{50}$ values for ferrous ion chelating activity (FICA) was $<0.1-0.455$ $\mathrm{mg} / \mathrm{mL}$, with the strongest and weakest $\mathrm{EC}_{50}$ noted in domesticated Amylosporus sp. IJ-2014 and L. sajor-caju, correspondingly. The maximum and minimum total phenolic content (TPC) recorded were 537.39 and $160.97 \mathrm{mg}$ GAE/100g, from domesticated Amylosporus sp. IJ-2014 and Laetiporus sp. IJ-2014, respectively. The highest and least quantities of $\beta$-carotene (BC) recorded were 48.59 and $5.56 \mathrm{mg} / 100 \mathrm{~g}$, from P. tenuiculus/wild Amylosporus sp. IJ-2014 and P. cystidiosus, respectively. Lycopene contents (LC) ranged from 2.24 to $18.95 \mathrm{mg} / 100 \mathrm{~g}$, with $P$. cystidiosus and $P$. tenuiculus having the slightest and peak values, correspondingly. Maximum value for total flavonoid contents (TFl) recorded was $25.27 \mathrm{mg} \mathrm{QE} / 100 \mathrm{~g}$ from $P$. tenuiculus whereas the minimum value was $3.71 \mathrm{mg}$ QE/100g from P. cystidiosus. Due to the antioxidant potentials of these mushrooms, people are advised to maximally exploit them for improved nutrition and health.
\end{abstract}

Keywords - 1, 1-Diphenyl-2-picrylhydazyl - Antioxidant - Ferrozine - Free radical - Saprophytic edible mushrooms 


\section{Introduction}

Antioxidants are chemical compounds that protect cells from free radical induced damages (Halliwell \& Gutteridge 1990). Free radicals damage cells gradually and are involved in development of some illnesses associated with diseases of diabetes mellitus, HIV infection, malignant tumor and inflammation (Papas 1999). There are internal and external sources of free radicals. Internal sources include nutrient metabolism, ageing process and inflammation whereas external sources include drugs, tobacco smoke, ionizing radiation, air pollution, organic solvents, pesticides and extreme exercise (Blokhina et al. 2003). When free radical reactions start within cells, they tend to spread to neighboring cells with increasing effect. They alter biomolecules such as proteins, lipids, carbohydrates and nucleic acids (Laguerre et al. 2007). Though naturally occurring antioxidants tend to prevent oxidative damages of free radical reactions in all organisms, they are inadequate to completely prevent those damages (Morgan \& Liu 2011, Siomek 2012). Supplementation by man-made antioxidants such as propyl gallate (PG) and tertiary butylhydroquinone (TBHQ) have been reported to have adverse, toxic effects (Kahl \& Kappus 1993). Consequently, the increased attention is paid to investigations and exploitation of antioxidant rich foods (Finley et al. 2011).

Recently, mushrooms have been reported as sources of physiological agents for medicinal applications and various therapeutic activities including antioxidants (Jose et al. 2002, Wong \& Chye 2009). There are several varieties of wild mushrooms whose medicinal profiles have not been described especially from developing countries (Wong \& Chye 2009). It has been established that extracts from fungi that have been obtained by methanolic extraction comprise various polyphenolic compounds including flavonoids, lycopene and $\beta$-carotenes (Muruke 2014, Tibuhwa 2014). Polyphenols are familiar for their large array of biological actions that include free radical scavenging and metal chelation activities (Burgosa et al. 2013).

Tanzania is endowed with natural forests harboring varieties of wild edible mushrooms which are meagerly exploited. Mushroom eating habit is more common in rural areas and relies exclusively on collection from the natural forests, eating them fresh or sun-drying them for long preservation (Tibuhwa 2014). Many people are doubtful about mushrooms as a valuable food source. Ignorance has led them to become suspicious about whether food of fungal origin can grasp any great nutritional assurance or antioxidant value (Crisan \& Sands 1978). It seems much education is needed before full advantage can be taken of this readily available, nutritionally and antioxidant rich food source (Crisan \& Sands 1978, Chang \& Mshigeni 2001). In Tanzania few studies have been conducted on antioxidant activities of edible mushrooms. For instance, Tibuhwa (2014) reported antioxidant activities of fresh and dry mushrooms in the genera Cantharellus and Afrocantharellus, Muruke (2014) reported antioxidant activities of Pleurotus cystidiosus whereas Hussein et al. (2015) reported antioxidant activities of six species of edible mushrooms. The present study complements the work by Hussein et al. (2015), it aimed at establishing the antioxidant potentials of seven species of wild saprophytic edible mushrooms and comparing between the wild and their respective domesticated forms.

\section{Materials \& Methods}

\section{Sample collection}

The study was conducted within natural forests of Lutindi, Shume-Magamba and Kieti in Tanga region, Kazimzumbwi forest in Pwani region and some planted trees at University of Dar es Salaam, Mwalimu JK Nyerere Mlimani Campus, in Dar es Salaam region. Mushroom samples were collected during rainy seasons (March-May and September-December, in 2011/2012). The collected mushrooms were identified using morphological and genetic markers (ITS and LSU regions of nuclear ribosomal DNA). Comprehensive study on identification of these mushrooms will be reported elsewhere. The identified wild edible saprophytic mushrooms were subjected to domestication trials as detailed by Juma et al. (2015). Domestication process started with isolation of mushroom germplasm in which sterile tissues of wild edible mushrooms were aseptically cultured on potato dextrose agar. 
Mycelia obtained were used to develop mushroom spawns using sorghum grains. Later on spawns were inoculated on prepared substrate, dry sugarcane tops, and then monitored for spawn running and fructification. The wild and successfully domesticated mushrooms were dried at $50^{\circ} \mathrm{C}$ to constant weight and then preserved in silica gel for nutritional and antioxidant assays. The studied mushroom samples are presented in Table 1.

\section{Determination of mushroom antioxidant activities}

Antioxidant activities of mushrooms were assayed by determining their free radical scavenging abilities and ferrous ion chelating capabilities. In connection to that the concentration of organic/phenolic compounds with antioxidant effects were evaluated.

\section{Crude extract preparation}

Methanolic extractions were carried according to Pal et al. (2010). $1 \mathrm{~g}$ of mushroom fruitbody from each sample was weighed and pounded using motor and pestle, then soaked in $250 \mathrm{~mL}$ of methanol. The soaked material was continuously stirred for 48 hours, later on filtered using filter paper (WHATMAN FILTER PAPER) and evaporated to dryness under reduced pressure, in a rotary evaporator (BUCHI R 210, SWITZERAND) with $90 \mathrm{rpm}$. The obtained concentrates were stored in dark at $4^{\circ} \mathrm{C}$ until further use. The percentage yield of the evaporated extracts was calculated based on dry weight according to Maisuthisakul et al. (2007) as follows:

Yield $(\%)=\left(\mathrm{W}_{1} / \mathrm{W}_{2}\right) * 100$

Where: $\mathrm{W}_{1}=$ Weight of extract after methanol evaporation

$\mathrm{W}_{2}=$ Dry weight of the mushroom sample

\section{DPPH free radical scavenging activity (DRSA)}

The 1, 1-diphenyl-2-picrylhydrazyl (DPPH) free radical scavenging activity was determined as per Cuendet et al. (1997) and Burits \& Bucar (2000). $1 \mathrm{~mL}$ of various concentrations (0.006-0.3 $\mathrm{mg} / \mathrm{mL}$ ) of the mushroom extracts in methanol was added to $4 \mathrm{~mL}$ of a $0.004 \%$ (w/v) methanol solution of DPPH. After a 5 min incubation period at room temperature the absorbance was read against a blank at $517 \mathrm{~nm}$ using a UV spectrophotometer (UV-VIS MODEL 6305 JENWAY UK). Inhibition of free radical DPPH (DPPH free radical scavenging activity) in percent was calculated in the following way:

DPPH free radical scavenging activity $(\%)=\left(\mathrm{A}_{\text {control }}-\mathrm{A}_{\text {sample }}\right) / \mathrm{A}_{\text {control }} * 100$

Where: $\mathrm{A}_{\text {control }}$ is the absorbance of the control reaction containing all reagents except mushroom extract and $\mathrm{A}$ Sample is the absorbance of the mushroom extract.

The $\mathrm{EC}_{50}$ value $(\mathrm{mg} / \mathrm{mL})$, which is the concentration of the extract/standard that reduces $50 \%$ of the free-radical concentration, was calculated through linear interpolation between values above and below $50 \%$ activity.

\section{Ferrous ion chelating activity (FICA)}

In this study, the ferrous ion chelating capacity assay was used to evaluate the ability of mushroom antioxidants to disrupt the formation of the complexes or to prevent interaction between transition metal ions and lipids. The assay for ferrous ion chelating ability was conducted as per the method described by HeimLer et at. (2007) with slight amendments. $0.05 \mathrm{~mL}$ of extracts $(0.006-0.3$ $\mathrm{mg}$ dry mushroom extract $/ \mathrm{mL}$ ) was pipetted in Eppendorf tubes, and then $0.7 \mathrm{~mL}$ of methanol and $0.0125 \mathrm{~mL}$ of $2.0 \mathrm{mM}$ ferrous chloride were added. Mixture was allowed to stand for $10 \mathrm{~min}$ at room temperature, and then $0.05 \mathrm{~mL}$ of $5.0 \mathrm{mM}$ ferrozine was added. The mixture was shaken and after 5 min the absorbance was measured at $562 \mathrm{~nm}$ using a UV spectrophotometer (UV-VIS MODEL 6305 JENWAY UK). EDTA served as the positive control, and a sample with methanol instead of mushroom extract served as the negative control (blank). The percent ferrous ion chelating ability was calculated according to the equation:

$$
\text { Chelating ability }(\%)=\left(\mathrm{A}_{0}-A_{1}\right) / A_{0} * 100
$$


Where: $A_{0}$ is the absorbance of the blank, and $A_{1}$ is the absorbance in the presence of sample (extract or standard)

The $\mathrm{EC}_{50}$ value $(\mathrm{mg} / \mathrm{mL})$, which is the concentration of the extract/standard that chelates $50 \%$ of the ferrous ion, was calculated through linear interpolation between values above and below 50\% activity.

\section{Total phenolic content (TPC)}

Total phenolic content was determined in mushrooms' methanolic extracts by the Folin-Ciocalteu assay, modified to micro-scale by Arnous et al. (2002). Briefly, $0.01 \mathrm{~mL}$ of extract was mixed with $0.79 \mathrm{~mL}$ distilled water and $0.05 \mathrm{~mL}$ Folin-Ciocalteu reagent in Eppendorf tubes. Tubes were vortexed and after 1 minute, $0.15 \mathrm{~mL}$ of saturated sodium carbonate solution were added. Following incubation of the mixture in the dark for two hours, the absorbance was measured at $750 \mathrm{~nm}$ using a UV spectrophotometer (UV-VIS MODEL 6305 JENWAY UK). Gallic acid was used as calibration standard and the results were expressed as $\mathrm{mg}$ gallic acid equivalents (mg GAE) per $100 \mathrm{~g}$ of dry mushroom.

\section{Determination of total flavonoids (TFl)}

Determination of total flavonoids was done with aluminium chloride as per Jaita et al. (2010) and Pitchaon et al. (2007) using quercetin as standard. $1 \mathrm{~mL}$ of each mushroom extract was mixed with $4.3 \mathrm{~mL}$ of $80 \%$ aqueous ethanol containing $0.1 \mathrm{~mL}$ of $10 \%$ aluminium nitrate and $0.1 \mathrm{~mL}$ of $1 \mathrm{M}$ aqueous potassium acetate. The mixture was left for 40 minutes at room temperature and then the absorbance was determined calorimetrically at $515 \mathrm{~nm}$ using a UV spectrophotometer (UV-VIS MODEL 6305 JENWAY UK). The total flavonoids concentration was calculated using quercetin standard calibration curve. Data were expressed as $\mathrm{mg}$ quercetin equivalent/100 $\mathrm{g}(\mathrm{mg} \mathrm{QE} / 100 \mathrm{~g})$ of mushroom extracted.

\section{Determination of $\beta$-carotene $(B C)$ and lycopene contents $(L C)$}

Assays of $\beta$-carotene and lycopene contents were carried out using the method of Nagata and Yamashita (1992). $100 \mathrm{mg}$ of a mushroom extract was shaken with $10 \mathrm{~mL}$ of Acetone-hexane mixture (92:3) for 1 minute and filtered through filter paper (WHATMAN NUMBER 4 FILTER PAPER). The absorbance of the filtrate was measured at 453, 505 and $663 \mathrm{~nm}$. The $\beta$-carotene and lycopene contents were calculated from the formulae:

$$
\begin{aligned}
& \text { Lycopene }(\mu \mathrm{g} / \mathrm{mg})=0.0458 A_{663}+0.372 A_{505}-0.0806 A_{453} \\
& \beta \text { - carotene }(\mu \mathrm{g} / \mathrm{mg})=0.216 A_{663}-0.304 A_{505}+0.452 A_{453}
\end{aligned}
$$

Where: $\mathrm{A}_{453}, \mathrm{~A}_{505}$ and $\mathrm{A}_{663}$ are absorbance at 453, 505 and $663 \mathrm{~nm}$ respectively.

\section{Data analysis}

Data on mushroom antioxidant potentials were subjected to analysis of variance (one-way ANOVA) and significance was accepted at 5\% probability level using statistical package for social science IBM SPSS 21 Version (SPSS 1999). Post hoc tests were made under SNK-Dunkan/LSD Waller. The results are presented as mean of two replicates. The letter ' $\mathbf{D}$ ' on sample names was used to distinguish domesticated mushrooms from their respective wild species.

\section{Results}

\section{DPPH free radical scavenging activity}

A fresh prepared DPPH solution was deep purple in colour which faded away as the DPPH free radicals were quenched and converted into a colourless product (2,2-diphenyl-1-hydrazine) resulting in absorbance decrease. Thus, the more rapidly the absorbance decreased the more effective was the antioxidant activity of the extract. The results for the radical scavenging activity are presented in Figure 1 and Table 1 . The highest activity was observed at the concentration of $0.3 \mathrm{mg} / \mathrm{mL}$ and it was in the 


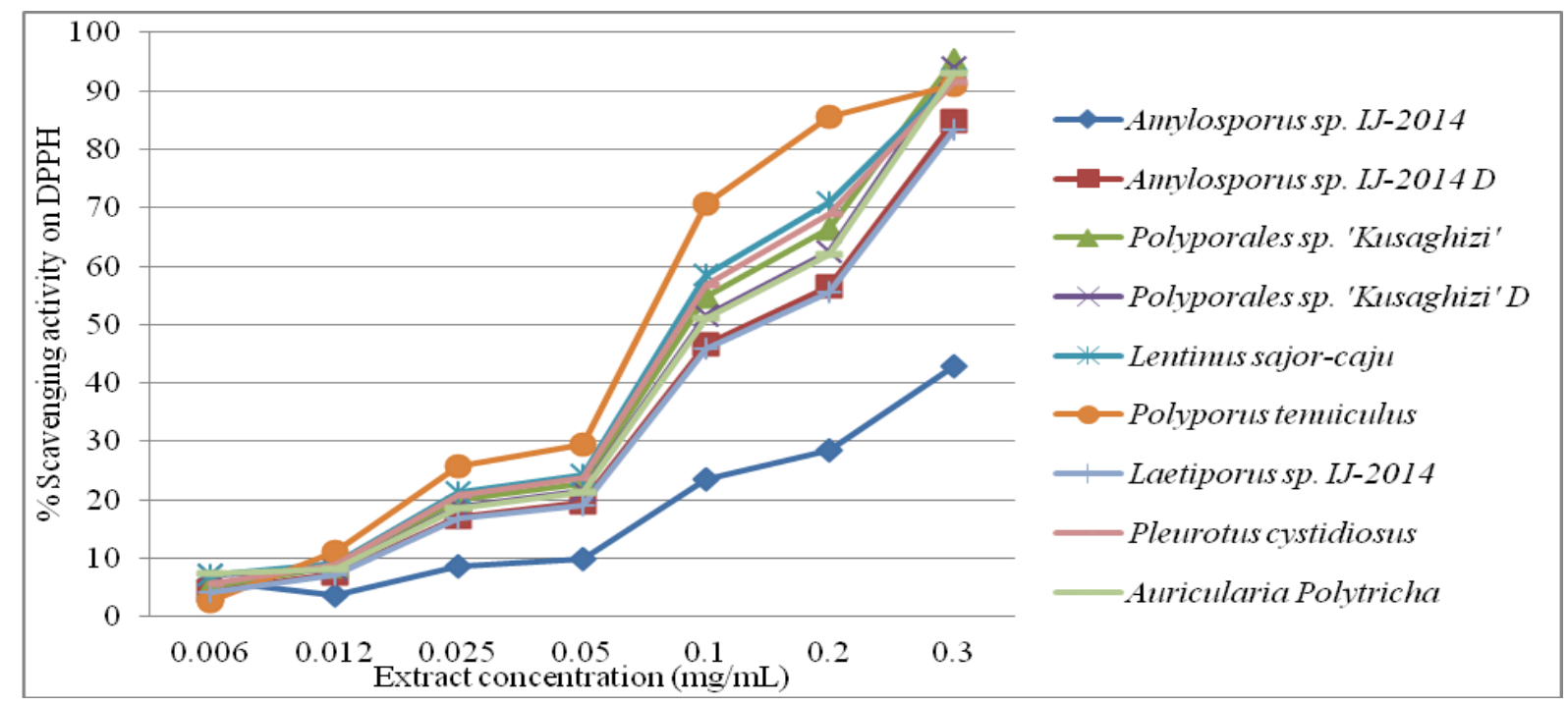

Fig. 1 - Percentage scavenging activity of mushroom extracts at different concentrations

wild form of Polyporales sp. 'Kusaghizi' (95.2\%) whereas the least activity was noted at $0.006 \mathrm{mg} / \mathrm{mL}$ from $P$. tenuiculus $(2.6 \%)$. The minimum $\mathrm{EC}_{50}$ value was that of $P$. tenuiculus $\left(\mathrm{EC}_{50}=0.075 \mathrm{mg} / \mathrm{mL}\right)$, signifying the strongest scavenging ability, whereas the maximum $\mathrm{EC}_{50}$ value was that of wild Amylosporus sp. IJ-2014 ( $\left.\mathrm{EC}_{50}>0.3 \mathrm{mg} / \mathrm{mL}\right)$, signifying the least radical scavenging ability.

\section{Ferrous ion chelating ability}

The results of ferrous ion chelating ability of mushroom extracts are presented in Figure 2 and Table 1. The highest ferrous ion chelating activity observed was $99.45 \%$ in A. polytricha at $0.7 \mathrm{mg} / \mathrm{mL}$ extract concentration whereas the least activity observed was $18.61 \%$ in $L$. sajor-caju at $0.1 \mathrm{mg} / \mathrm{mL}$ extract concentration. The lowest $\mathrm{EC}_{50}$ value was observed in the domesticated Amylosporus $s p$. $I J-2014\left(\mathrm{EC}_{50}<0.1 \mathrm{mg} / \mathrm{mL}\right)$, signifying the highest ferrous ion chelating ability while the highest $\mathrm{EC}_{50}$ value was that of L. sajor-caju $\left(\mathrm{EC}_{50}=0.455 \mathrm{mg} / \mathrm{mL}\right)$, implying the least ferrous ion chelating ability.

Table 1 Extract yield (EY), lycopene content (LC), $\beta$-carotene (BC), total flavonoids (TFl), and total phenolic contents (TPC) in edible mushrooms with $\mathrm{EC}_{50}$ for DPPH free radical scavenging activity (DRSA) and ferrous ion chelating activity (FICA)

\begin{tabular}{|c|c|c|c|c|c|c|c|c|}
\hline Mushroom samples & Voucher & $\begin{array}{l}\mathrm{EC}_{50^{-}} \\
\text {DRSA } \\
(\mathrm{mg} / \\
\mathrm{mL})\end{array}$ & $\begin{array}{l}\text { EC }_{50}^{-} \\
\text {FICA } \\
(\mathrm{mg} / \\
\mathrm{mL})\end{array}$ & $\begin{array}{l}\mathbf{E Y} \\
(\%)\end{array}$ & $\begin{array}{c}\text { TPC } \\
(\mathrm{mg} \\
\text { GAE/ } \\
\mathbf{1 0 0 g})\end{array}$ & $\begin{array}{c}\mathrm{BC} \\
(\mathrm{mg} / \\
100 \mathrm{~g})\end{array}$ & $\begin{array}{c}\text { LC } \\
\text { (mg/ } \\
\text { 100g) }\end{array}$ & $\begin{array}{c}\text { TFl } \\
\text { (mg } \\
\text { QE/ } \\
\text { 100g) }\end{array}$ \\
\hline Amylosporus sp. IJ-2014 & IJV29-1 & $>0.3$ & 0.275 & 13.48 & 390.24 & 48.59 & 12.33 & 16.43 \\
\hline Amylosporus sp. IJ-2014 D & IJV29-2 & 0.132 & $<0.1$ & 17.95 & 247.96 & 36.14 & 14.16 & 23.11 \\
\hline Auricularia polytricha & IJV46 & 0.097 & 0.345 & 10.05 & 186.99 & 12.5 & 5.6 & 9.25 \\
\hline Laetiporus sp. IJ-2014 & IJV38 & 0.142 & 0.168 & 26.55 & 160.97 & 45.26 & 17.76 & 23.67 \\
\hline Lentinus sajor-caju & IJV50 & 0.086 & 0.455 & 28.91 & 182.73 & 30.28 & 11.84 & 15.78 \\
\hline Pleurotus cystidiosus & IJV35 & 0.088 & 0.375 & 4.82 & 237.39 & 5.56 & 2.24 & 3.71 \\
\hline Polyporales sp. 'Kusaghizi' & IJV40-1 & 0.092 & 0.1 & 39.67 & 428.46 & 35.16 & 14.09 & 18.78 \\
\hline Polyporales sp. 'Kusaghizi’D & IJV40-2 & 0.097 & 0.25 & 37.87 & 537.39 & 41.28 & 16.18 & 21.57 \\
\hline Polyporus tenuiculus & IJV34 & 0.075 & 0.327 & 29 & 416.26 & 48.59 & 18.95 & 25.27 \\
\hline
\end{tabular}

NOTE: The letter ' $\mathbf{D}$ ' in mushroom samples was used to differentiate domesticated mushrooms from the wild mushrooms. 


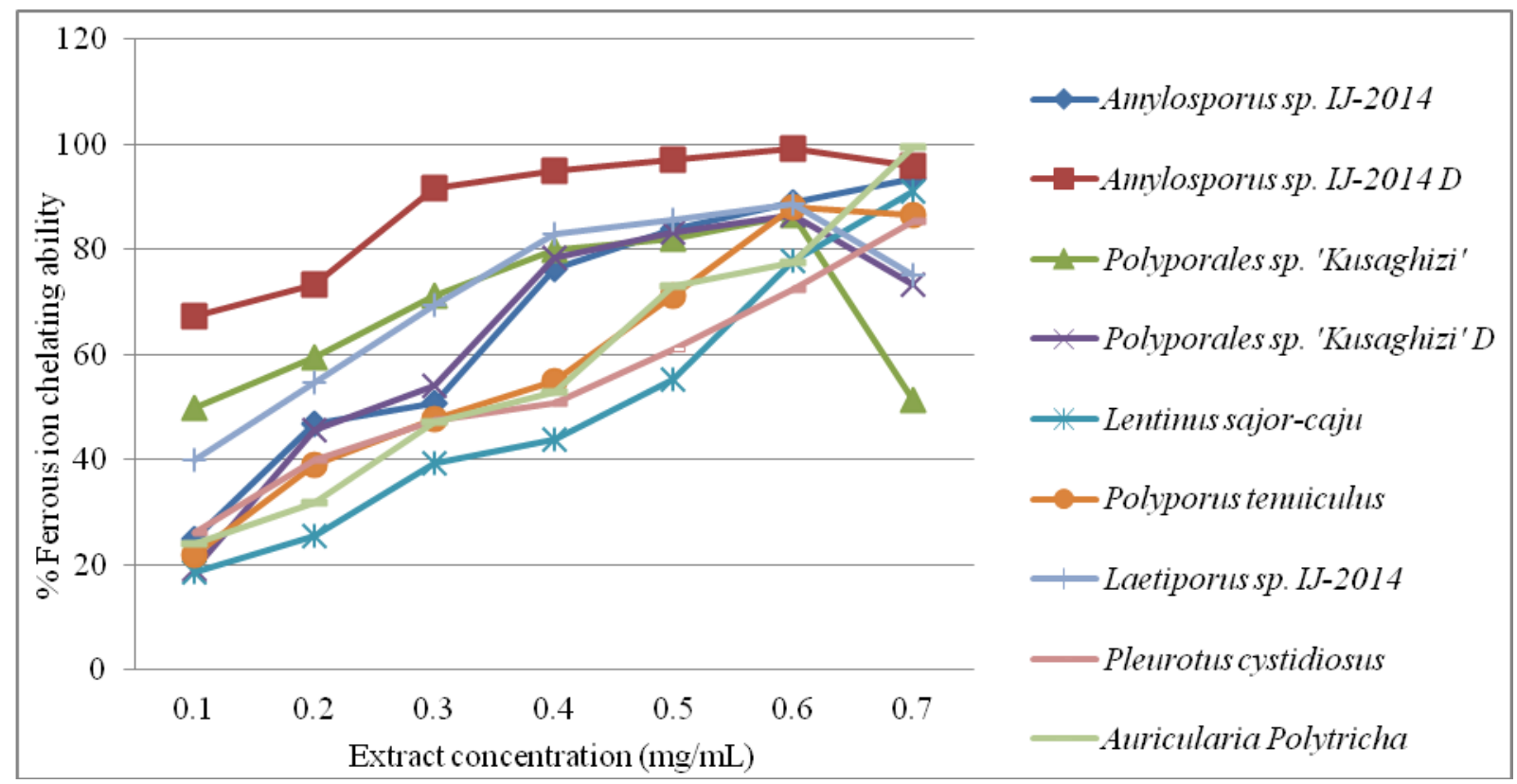

Fig. 2 - Ferrous ion chelating ability of mushroom extracts at different concentrations

\section{Total phenolic compounds, flavonoids, lycopene and $\beta$-carotene contents}

The results for total phenolic compounds, flavonoids, lycopene and $\beta$-carotene contents of the mushrooms are presented in Table 1 . The extract yield ranged from 4.82 to $39.67 \%$, with $P$. cystidiosus and Polyporales sp. 'Kusaghizi' possessing the least and highest values, respectively. Total phenolic content range was 160.97-537.39 mg GAE/100g, with the least and the highest values recorded from Laetiporus sp. IJ-2014 and domesticated Amylosporus sp. IJ-2014, respectively. The minimum and maximum values for $\beta$-carotene were 5.56 and $48.59 \mathrm{mg} / 100 \mathrm{~g}$, and were recorded from $P$. cystidiosus and P. tenuiculus/wild Amylosporus sp. IJ-2014, respectively. Lycopene contents ranged from 2.24 to $18.95 \mathrm{mg} / 100 \mathrm{~g}$, with $P$. cystidiosus and $P$. tenuiculus having the slightest and peak values, correspondingly. Maximum value for flavonoid contents recorded was $25.27 \mathrm{mg} Q \mathrm{QE} / 100 \mathrm{~g}$ from $P$. tenuiculus whereas the minimum value was $3.71 \mathrm{mg} \mathrm{QE} / 100 \mathrm{~g}$ from $P$. cystidiosus.

\section{Discussion}

\section{DPPH free radical scavenging activity}

The results from this study depicted variation in mushroom radical scavenging ability not only between different species, but also between domesticated and wild forms of the same species. A. polytricha and domesticated Polyporales sp. 'Kusaghizi' possessed the same $\mathrm{EC}_{50}$ value of 0.097 $\mathrm{mg} / \mathrm{mL}$ which was a bit higher to that of the wild Polyporales sp. 'Kusaghizi' with $0.092 \mathrm{mg} / \mathrm{mL}$. The EC $_{50}$ value of $P$. cystidiosus was $0.088 \mathrm{mg} / \mathrm{mL}$ and is within a range of $0.0359-0.1500 \mathrm{mg} / \mathrm{mL}$ reported by Muruke (2014) for the same species. L. sajor-caju and P. tenuiculus possessed $\mathrm{EC}_{50}$ values of 0.086 and $0.075 \mathrm{mg} / \mathrm{mL}$, respectively, which are lower than the values reported by Hussein et al. (2015) for the same species, 0.23 and $0.098 \mathrm{mg} / \mathrm{mL}$, correspondingly. In this study, the range of $\mathrm{EC}_{50}$ values for DPPH scavenge in all mushrooms was $0.075->0.3 \mathrm{mg} / \mathrm{mL}$, which is in agreement to the range of $0.08->0.3 \mathrm{mg} / \mathrm{mL}$ reported by Hussein et al. (2015). With the exception of the wild Amylosporus sp. IJ-2014 and Laetiporus sp. IJ-2014 the range of $\mathrm{EC}_{50}$ values in all mushrooms investigated was $\quad 0.075-0.1 \mathrm{mg} / \mathrm{mL}$ unlike those from the genera Cantharellus and Afrocantharellus studied by Tibuhwa (2014) which portrayed the $\mathrm{EC}_{50}$ values $>0.1 \mathrm{mg} / \mathrm{mL}$. In the same study Tibuhwa indicated that the scavenging ability is higher in the fresh mushrooms than their dry counterparts. Since all mushroom species analysed in this study were dry, it is expected that their fresh counterparts could have even higher scavenging ability. 


\section{Ferrous ion chelating ability}

The ferrous ion chelating capability of mushrooms varied between different species and also between domesticated and wild forms of the same species. The wild Polyporales sp. 'Kusaghizi' demonstrated $\mathrm{EC}_{50}$ value which is more effective than that of its domesticated form by $150 \%$. Conversely, the domesticated Amylosporus sp. IJ-2014 demonstrated $\mathrm{EC}_{50}$ value which is more effective than that of its wild form by $>175 \%$. The $\mathrm{EC}_{50}$ value of $P$. tenuiculus, $0.327 \mathrm{mg} / \mathrm{mL}$, is lower than that reported by Hussein et al. (2015), $0.59 \mathrm{mg} / \mathrm{mL}$, for the same species. The $\mathrm{EC}_{50}$ value of P. cystidiosus, $0.375 \mathrm{mg} / \mathrm{mL}$, is higher than the range reported by Muruke (2014), $0.0911-0.2270$ $\mathrm{mg} / \mathrm{ml}$, for the same species. Likewise, the $\mathrm{EC}_{50}$ value of $L$. sajor-caju, $0.455 \mathrm{mg} / \mathrm{mL}$, is higher than that reported by Hussein et al. (2015) for the same species, $0.37 \mathrm{mg} / \mathrm{ml}$. The range of $\mathrm{EC}_{50}$ values for ferrous ion chelation was $<0.1-0.455 \mathrm{mg} / \mathrm{mL}$, which is comparable to the range of $0.12->0.59$ $\mathrm{mg} / \mathrm{mL}$ reported by Hussein et al. (2015). Ferrous ions are acknowledged as the most effective pro-oxidant among various species of metal ions due to its high reactivity, which hasten lipid oxidation by breaking down hydrogen and lipid peroxidase to reactive free radicals through the Fenton type reaction. Metal chelating activity is an antioxidant mechanism, since it reduces the concentration of the catalyzing transition metal ions in lipid peroxidation (Qiao et al. 2009). The higher chelating abilities of the studied mushrooms suggest that they are a very useful food source, with powerful antioxidant abilities.

\section{$\beta$-carotene contents}

From the analysed mushroom extracts, all species owned organic compounds with antioxidant potentials in concentrations, which varied markedly between species and also between the wild and domesticated forms of the same species. $\beta$-Carotene is known to be precursor for the synthesis of vitamin A, which acts as powerful antioxidants (Ross et al. 2011). The range of $\beta$-carotene in the investigated edible mushrooms was $5.56-48.59 \mathrm{mg} / 100 \mathrm{~g}$ which is comparable to the range of $5.35-48.15 \mathrm{mg} / 100 \mathrm{~g}$ reported by Hussein et al. (2015) for the wild edible mushrooms. In the present study, the $\beta$-carotene content values for $L$. sajor-caju and $P$. tenuiculus were 30.28 and $48.59 \mathrm{mg} / 100 \mathrm{~g}$, respectively which are higher than that reported by Hussein et al. (2015), 5.35 and $37.10 \mathrm{mg} / 100 \mathrm{~g}$, for the same species, respectively. Muruke (2014) reported P. cystidiosus to have $\beta$-carotene content level of $2-45 \mathrm{mg} / 100 \mathrm{~g}$, which is in agreement with the value reported by this study for the same species. The $\beta$-carotene contents level was found to be higher in the wild Amylosporus sp. IJ-2014 (48.59 mg/100g) compared to its domesticated form $(36.14 \mathrm{mg} / 100 \mathrm{~g})$ but lower in the wild Polyporales sp. 'Kusaghizi' $(35.16 \mathrm{mg} / 100 \mathrm{~g})$ compared to its domesticated form $(41.28 \mathrm{mg} / 100 \mathrm{~g})$.

\section{Lycopene contents}

Lycopene is the most efficient singlet oxygen quencher compared with a variety of carotenoids (Chung et al. 1998) and it is three times more efficient than $\beta$-carotene in preventing lipid peroxidation in multi lamellar liposomes (Stahl et al. 1998). The lycopene content range observed in this study, 2.24-18.95 mg/100g, is in agreement with the study by Hussein et al. (2015) who reported a range of $2.16-18.32 \mathrm{mg} / 100 \mathrm{~g}$ for the wild edible mushrooms. Besides, the lycopene content range of the present study is lower than that reported by Muruke (2014), 10-65 mg/100g, for P. cystidiosus. L. sajor-caju and $P$. tenuiculus observed to have lycopene contents of 11.84 and $18.95 \mathrm{mg} / 100 \mathrm{~g}$, respectively which are higher than that reported by Hussein et al. (2015) for the same wild mushroom species; 2.16 and $15.02 \mathrm{mg} / 100 \mathrm{~g}$ for $L$. sajor-caju and P. tenuiculus, respectively. The lycopene contents noticed to be higher in domesticated mushrooms compared to their counterparts' wild species by $14.84 \%$ and $14.83 \%$ for Amylosporus sp. IJ-2014 and Polyporales sp. 'Kusaghizi', respectively. It is very fascinating to note that the studied mushrooms had such high amounts of lycopene, which is a very good indicator of them being a good source of nutraceuticals. For comparison, the content of carotenoids ( $\beta$-carotene and lycopene) reported by Ben-Amotz and Fishler (1998) in vegetables ranges from undetectable levels to $\sim 5.28 \mathrm{mg} / 100 \mathrm{~g}$ for persimmon, $\sim 53.21 \mathrm{mg} / 100 \mathrm{~g}$ for pitango, $\sim 103$ $\mathrm{mg} / 100 \mathrm{~g}$ for carrot and $\sim 24.31 \mathrm{mg} / 100 \mathrm{~g}$ for tomato. This clearly showed that the amounts of $\beta$-carotene and lycopene in the studied mushrooms are in abundance compared to the concentration 
reported in some vegetables and other mushrooms, which implies that these mushrooms could be a good alternative source of carotenoids.

\section{Total flavonoids contents}

In this study, total flavonoids content range was 3.71-25.27 $\mathrm{mg} \mathrm{QE} / 100 \mathrm{~g}$, which is comparable to the range of 3.81-25.62 mg QE/100g reported by Hussein et al. (2015). Furthermore, Hussein et al. (2015) reported 2.49 and $20.86 \mathrm{mg} \mathrm{QE} / 100 \mathrm{~g}$ as flavonoid contents for L. sajor-caju and P. tenuiculus, respectively. These values are lower than the ones noted by this study, 15.78 and $25.27 \mathrm{mg} \mathrm{QE} / 100 \mathrm{~g}$ for L. sajor-caju and P. tenuiculus, respectively. Muruke (2014) reported total flavonoids content values of 5-31.64 mg QE/100g for P. cystidiosus, which is higher than that reported by this study for the same species. The study by Tibuhwa (2014) reported higher flavonoid amount from fresh form of Afrocantharellus splendens and Cantharellus rufopunctatus (155.16 and $134.31 \mathrm{mg} \mathrm{QE} / 100 \mathrm{~g}$, respectively), which are also extremely higher than the peak value recorded by this study. The domesticated mushrooms observed to have higher flavonoid contents than their relevant wild species by $40.66 \%$ and $14.86 \%$ for Amylosporus sp. IJ-2014 and Polyporales sp. 'Kusaghizi', correspondingly. High flavonoids level may help provide protection against oxidative stress induced diseases by contributing along with other antioxidant vitamins and enzyme to the total antioxidative defense system of the human body (Tripathy et al. 2014).

\section{Total phenolic contents}

Polyphenolic compounds are recognized as excellent antioxidants not only because of their ability to scavenge free radicals by single electron transfer (Mau et al. 2004) but also because of their stable radical intermediates (Shahidi \& Wanasundra 1992). In the present study, the level of total phenolic contents in investigated mushrooms was $160.97-537.39 \mathrm{mg}$ GAE/100g, which is higher than the level reported by Hussein et al. (2015), 136.21-431.03 mg GAE/100g. In the same study, Hussein et al. (2015) reported phenolic contents values of $162.74 \mathrm{mg}$ GAE/100g for L. sajor-caju, which is lower than the one observed in this study for the same species $(182.73 \mathrm{mg}$ GAE/100g), and $431.03 \mathrm{mg}$ GAE/100g for $P$. tenuiculus, which is higher than that obtained in this study for the same species (416.26 mg GAE/100g). Muruke (2014) reported phenolic contents level of up to $99.26 \mathrm{mg}$ GAE/100g for $P$. cystidiosus, which is lower than the value obtained in this study for the same species $(237.39 \mathrm{mg}$ GAE/100g). Tibuhwa (2014) observed a positive correlation between mushroom total phenolic contents and their radical scavenging effects. In the present study, no correlation observed between mushroom phenolic contents and their antioxidant activities. This proposes that in addition to total phenolic contents, the variety of phenolic compounds and the proportion among them are equally imperative for determining the antioxidant potential as it was previously noted by Robu et al. (2012). Variation in antioxidant potentials between different mushroom species and between domesticated and wild forms of the same species was influenced by a number of factors including genetic nature of each species, age and parts (stipe or pileus) of mushrooms analysed as well as variation in composition of growth substrates and environmental factors (water, temperature and humidity).

\section{Conclusion}

Findings of this study revealed that the studied saprophytic edible mushrooms have amazing antioxidant activity with significant amounts of $\beta$-Carotene, lycopene, flavonoids and total phenolic compounds. Thus, people are advised to maximally exploit them for improved healthiness. Health individuals can become more industrious and better use their psychological and physiological potential for their personal development and that of their country, Tanzania.

\section{Acknowledgement}

The authors are thankful to the Australian Government (AusAID) through, A BecA- ILRI hub-CSIRO for their financial support on the Mushroom project (Project No. CS1002-MUS) conducted at the Department of Molecular Biology \& Biotechnology, University of Dar es Salaam, Tanzania. 


\section{References}

Arnous A, Makris DP, Kefalas P. 2002 - Correlation of pigment and flavanol content with antioxidant properties in selected aged regional wines from Greece. Journal of Food Composition Analysis $15,655-665$.

Banerjee S, Sanjay KR, Chethan S, Malleshi NG. 2012 - Finger millet (Eleusine coracana) polyphenols: Investigation of their antioxidant capacity and antimicrobial activity. African Journal of Food Science 6 (13), 362-374.

Ben-Amotz A, Fishler R. 1998 - Analysis of carotenoids with emphasis on 9-cis $\beta$-carotene in vegetables and fruits commonly consumed in Israel. Food Chemistry 62, 515-520.

Blokhina O, Virolainen E, Fagerstedt KV. 2003 - Antioxidants, oxidative damage and oxygen deprivation stress: a review. Annals of Botany 91, 179-194.

Burgosa G, Amorosa W, Munoaa L, Sosaa P, Cayhuallaa E, Sancheza C, Diazb C, Bonierbalea M. 2013 - Total phenolic, total anthocyanin and phenolic acid concentrations and antioxidant activity of purple-fleshed potatoes as affected by boiling. Journal of Food Composition and Analysis 30 (1), 6-12.

Burits M, Bucar F. 2002 - Antioxidant activity of Nigella sativa essential oil. Phytotherapy Research $14,323-328$.

Chang ST, Mshigeni EK. 2001 - Proceedings of mushroom farming training workshop held at Bunda College of Agriculture, Lilongwe, Malawi, 12- 16 February, 2001. Promoting sustainable Human development in Africa. UNDP/UNOPS Reginal Project RAF/99/021. 150 pp.

Chung KT, Wong TY, Huang YW, Lin Y. 1998 - Tannins and human health: a review. Critical Reviews in Food Science 38, 421-464.

Crisan EV, Sands A. 1978 - Nutritional value. In: Chang ST, Hayes WA (Eds). The biology and cultivation of edible mushrooms. London, Academic Press Inc. 137-165.

Finley JW, Kong AN, Hintze KJ, Jeffery EH, Ji LL, Lei XG. 2011 - Antioxidants in foods: state of the science important to the food industry. Journal of Agricultural and Food Chemistry 59, 6837-6846.

Halliwell B, Gutteridge JMC. 1990 - Role of free radicals and catalytic metal ions in human disease: an overview. Methods in Enzymology 186, 1-85.

HeimLer D, Isolani L, Vignolini P, Tombelli S, Romani A. 2007 - Polyphenol content and antioxidative activity in some species of freshly consumed salads. Journal of Agricultural and Food Chemistry 55, 1724-1729.

Hussein JM, Tibuhwa DD, Mshandete AM, Kivaisi AK. 2015 - Antioxidant properties of seven wild edible mushroomms from Tanzania. African Journal of Food Science 9(9), 47-479.

Jaita P, Sourav G, Saifa AT, Krishnendu A. 2010 - In vitro free radical scavenging activity of wild edible mushroom, Pleurotus squarrosulus (Mont.) Singer. Indian Journal of Experimental Biology 47 (12), 1210-1218.

Jose N, Ajith TA, Janardhanan KK. 2002 - Antioxidant, anti-inflammatory and antitumor activities of culinary medicinal mushroom Pleurotus pulmonarius (Fr) Quel. (Agaricomycetideae). International Journal of Medicinal Mushrooms 4(4), 329-335.

Juma I, Tibuhwa DD, Mshandete AM, Kivaisi AK. 2015 - Domestication of seven Tanzanian indigenous saprophytic edible mushrooms. International Research Journal of Biological Sciences 4(12), 1-8.

Kahl R, Kappus H. 1993 - Toxicology and the synthetic anti-oxidants BHA and BHT in comparison with the natural antioxidant vitamin E. Z Lebensm Unters Forsch 196, 329-338.

Laguerre M, Lecomte J, Villeneuve P. 2007 - Evaluation of the ability of antioxidants to counteractlipid oxidation: Existing methods, new trends and challenges. Progress in Lipid Research 46, 244-282.

Maisuthisakul P, Sultajit M, Pongsawatmanit R. 2007 - Assessment of phenolic content and free radical scavenging capacity of some Thai indigenous plants. Food Chemistry 100, 1409-1418. 
Mau JL, Chang CN, Huang SJ, Chen CC. 2004 - Antioxidant properties on methanolic extracts from Grifola frondosa, Morchella esculenta and Termitomyces albuminosus mycelia. Food Chemistry 87, 111.

Morgan MJ, Liu ZG. 2011 - Review: Crosstalk of reactive oxygen species and NF-kB signaling. Cell Research 21, 103-115.

Muruke MH. 2014 - Evaluation of antioxidant and iron chelating activities of a wild edible oyster mushroom Pleurotus cystidiosus from Tanzania. Food Science and Quality Management 29, 1828.

Nagata M, Yamashita I. 1992 - Simple method for simultaneous determination of chlorophyll and carotenoids in tomato fruit. Nippon Shokuhin Kogyo Gakkaish 39 (10), 925-928.

Pal J, Ganguly S, Tahsin KS, Acharya K. 2010 - Invitro free radical scavenging activity of wild edible mushroom, Pleurotus squarrosulus (mont) Singer. Indian Journal of Experimental Biology 47, 1210-1218.

Papas AM. 1999 - Antioxidant status, diet, nutrition and health. CRC Press, Boca Raton, FL.

Pitchaon M, Maitree S, Rungnaphar P. 2007 - Assessment of phenolic content and free radicalscavenging capacity of some Thai indigenous plants. Food Chemistry 100 (4), 1409-1418.

Qiao DL, Ke CL, Hu B, Luo JG, Ye H, Sun Y, Yan XY, Zeng XX. 2009 - Antioxidant activities of polysaccharides from Hyriopsis cumingii. Carbohydrate Polymers 78, 199-204.

Robu S, Aprotosoaie AC, Miron A, Cioancă O, Stănescu U, Hăncianu M. 2012 - In vitro antioxidant activity of ethanolic extracts from some Lavandula species cultivated in Romania. Farmacia 60 (3), 394-401.

Ross AC, Chen Q, Ma Y. 2011 - Vitamin A and retinoic acid in the regulation of $\beta$-cell development and antibody production. Vitamins and Hormones 86, 103-126.

Shahidi F, Wanasundara PK. 1992 - Phenolic antioxidants. Critical Review of Food Sciences Nutrition 32, 67-103.

Siomek A. 2012 - Review: NF- $\kappa$ B signaling pathway and free radical impact. Acta Biochimica Polonica 59, 323-331.

SPSS. 1999 - Statistical package for social sciences, Computer program, MS for Windows, SPSS 21 for Windows, Chicago, Illinois, USA.

Stahal W, Junghans A, de Boer AB, Driomina ES, Briviba K, Sies H. 1998 - Carotene mixture protects multilamellar liposomes against oxidative damage: Synergistic effects of lycopene and lutein. FEBS Letters 427 (2), 305-308.

Tibuhwa DD. 2014 - A comparative study of antioxidant activities between fresh and dry mushrooms in the genera Cantharellus and Afrocantharellus from Tanzania. Food and Nutrition Sciences 5, 212-221.

Tripathy SS, Rajoriya A, Gupta N. 2014 - Wild mushrooms of Odisha: Prospective candidates of antioxidant sources. Advances in Plants \& Agriculture Research 1, 4-12.

Wong JY, Chye FY. 2009 - Antioxidant properties of selected tropical wild edible mushrooms. Journal of Food Composition and Analysis 22 (4), 269-277. 